\title{
Industry 4.0 and BIM: Do They Share the Same Objectives?
}

\author{
Laurent Joblot ${ }^{1(\bowtie)}$, Christophe Danjou ${ }^{2}$, Robert Pellerin ${ }^{2}$, and Samir Lamouri ${ }^{1}$ \\ 1 LAMIH-UMR CNRS 8201, Arts et Métiers, Paris, France \\ Laurent. joblot@ensam. eu \\ 2 Polytechnique Montréal, Montreal, Canada
}

\begin{abstract}
In recent years, many changes have been taking place within the construction sector which is much more prone to innovate than in the past. New forms of processes are emerging with the introduction of digital technologies. This article aims to shed light on recent scientific advances that link Industry 4.0 to this sector. To this end, a review of articles published over the past 10 years reporting experiences and gains from 4.0 technologies applied to construction was conducted. It turns out that recent technological developments have brought new functionalities and new perspectives to companies. Some of these were not initially claimed with the sole deployment of a BIM approach. These new opportunities have ultimately raised questions as to whether and how they could impact the speed at which a digital transformation of the sector could take place.
\end{abstract}

Keywords: Building Information Modeling (BIM) - Industry 4.0 (Ind4.0) ·

Digital transformation · Construction industry

\section{Context of the Study}

The construction industry plays a key role in the global economy. Despite its importance, it is still described as less productive and innovative than other sectors. However, this situation seems to be changing and several actors have recognized the need to innovate to ensure their competitiveness. New forms of work are emerging thanks to the introduction of technologies linked to Industry 4.0 (Ind4.0). In France and Quebec, several large companies have already adopted such technologies (BIM, virtual and augmented reality, prefabrication, the Internet of Things (IoT), additive manufacturing, robotization, etc.), but their implementation is still in its infancy, particularly among small businesses. These solutions must be encouraged in order to create a true digital transformation of construction. However, companies are still reluctant, not always knowing how to proceed or prioritize and what these technologies can actually bring to them.

In order to help various partners (French and Canadian companies), we felt it necessary to shed light on recent scientific advances that link Industry 4.0 and the construction sector. Several questions emerged at the beginning of our study in June 2019. The one we will try to answer here is, "What is the relationship between Industry 4.0 and BIM? Do these concepts share the same objectives when applied to the construction sector?"

(C) The Author(s) 2021

L. Roucoules et al. (Eds.): JCM 2020, LNME, pp. 412-418, 2021.

https://doi.org/10.1007/978-3-030-70566-4_65 
To answer this question, in the following section we will first present the strategy of the systematic literature review conducted on these questions. A synthesis of the 58 selected articles is then presented in part 3. Part 4 proposes then a deeper analysis of the content, and finally the conclusion sheds light on these recent functionalities and industrial opportunities. Some of these have not been previously when it came to exploiting the BIM model alone.

\section{Research Methodology}

To characterize the contributions of Ind4.0 in the construc tion sector, we first provide a review of the studies on this subject published prior to June 2019. To do so, we have analyzed the scientific publications using the SCOPUS database ${ }^{1}$ and post-2010 studies. The query focuses on title, abstract and author keywords on terms related to the construction sector and Ind4.0 in the broadest sense. This initial work made it possible to filter the available publications and to highlight 347 documents. In order to respond to our issue, we chose to study in detail only the articles using "allow or target or objective or aim or goal" in the title, abstract or keywords. This additional filter made it possible to keep only articles that openly claimed an intention or purpose. The 68 articles that responded to this new query and that could provide clarification to our partners are detailed and analyzed in the following section.

\section{Content of the Selected Papers}

After an in-depth study of the selected articles, 10 turned out to be irrelevant. The technologies tested and the experiments carried out ultimately led to many advances presented in these articles and listed in Table 1 below $^{2}$ :

Numerous overlaps and convergences were thus revealed. For example, items in bold in the table had an environmental intent. The following section therefore seeks to define what might be the "major families" of advances brought about by Industry 4.0 technologies in the construction sector.

\footnotetext{
${ }^{1}$ Query used: ((TITLE-ABS(“construct* indus*” OR "indus* construct*” OR "build* indus*” OR "indus* build*" OR "innovat* construct*" OR "innovat* build*" OR "construct* site*" OR "building system*” OR "construction sector*”) OR AUTHKEY(“construct* indus*” OR "indus* construct*" OR "build* indus*" OR "indus* build*" OR "innovat* construct*" OR "innovat* build*" OR "construct* site*" OR "building system*" OR "construction sector*") OR (TITLE("BIM" OR "building information model*") OR ABS ("BIM" OR "building information model*") OR AUTHKEY("BIM" OR "building information model*"))) AND ((TITLE("indus* 4.0" OR "build* 4.0" OR "techno* 4.0" OR "revolution* 4.0" OR "construct* 4.0") OR ABS("indus* 4.0" OR "build* 4.0" OR "techno* 4.0" OR "revolution* 4.0" OR "construct* 4.0") OR AUTHKEY ("indus* 4.0" OR "build* 4.0" OR "techno* 4.0" OR "revolution* 4.0" OR "construct* 4.0") OR TITLE ("digiti*” OR “digitali*” OR "digit* construct*” OR "digit* build*").

${ }^{2}$ Upon request, the corresponding author can send all of the references that were selected for this study.
} 
Table 1. List of recognized purposes and gains.

\begin{tabular}{|c|c|}
\hline $\begin{array}{l}\text { Improve management of resources and reduce } \\
\text { project duration and payment disputes }\end{array}$ & $\begin{array}{l}\text { Monitoring of planning/creation of a } \\
\text { "knowledge/experience" database }\end{array}$ \\
\hline Improve performance/increase collaboration & Increase interoperability \\
\hline $\begin{array}{l}\text { Continuous and integrated information } \\
\text { exchange and sharing }\end{array}$ & $\begin{array}{l}\text { Ease the transfer of architectural shapes into } \\
\text { reality }\end{array}$ \\
\hline $\begin{array}{l}\text { Improve real-time monitoring/discover } \\
\text { mismatch between the real discharging place } \\
\text { and the target/collect data for construction } \\
\text { organizing optimization/quantify logistic } \\
\text { density }\end{array}$ & $\begin{array}{l}\text { Increase sustainable development/ease } \\
\text { management of production/production } \\
\text { optimization (3D printers)/optimize } \\
\text { production to survive in the global market }\end{array}$ \\
\hline $\begin{array}{l}\text { Deliver greater value/addressing } \\
\text { sustainability/zero carbon and enhanced } \\
\text { resilience objectives }\end{array}$ & $\begin{array}{l}\text { High performance mobile mapping enables a } \\
\text { paradigm shift in the way buildings are } \\
\text { designed, tested, built, maintained and } \\
\text { refurbished }\end{array}$ \\
\hline $\begin{array}{l}\text { (Precast concrete and 3D printing) increase } \\
\text { creativity and thermal characteristics }\end{array}$ & $\begin{array}{l}\text { Enhance communication/increase ability to } \\
\text { manage communication }\end{array}$ \\
\hline $\begin{array}{l}\text { Accelerate (more accurate) data acquisition } \\
\text { (real time)/reduce time for data analysis }\end{array}$ & $\begin{array}{l}\text { Reduce complexity and uncertainty/enhance } \\
\text { information exchange }\end{array}$ \\
\hline $\begin{array}{l}\text { Transform and facilitate construction } \\
\text { operations }\end{array}$ & More sustainable approach \\
\hline $\begin{array}{l}\text { Increase competitiveness thanks to BIM } \\
\text { implantation }\end{array}$ & $\begin{array}{l}\text { Organize information, processes, people, } \\
\text { and/or firms }\end{array}$ \\
\hline Mass-customisation/Modularisation & Increase productivity \\
\hline $\begin{array}{l}\text { Reduction of conflicts/improve project } \\
\text { collaboration }\end{array}$ & $\begin{array}{l}\text { Improve the management of complexity of } \\
\text { information flow }\end{array}$ \\
\hline Achieve goals of construction projects & $\begin{array}{l}\text { Real-time construction progression } \\
\text { monitoring }\end{array}$ \\
\hline $\begin{array}{l}\text { Provide simulation and optimization to the } \\
\text { current processes }\end{array}$ & $\begin{array}{l}\text { Ensure the efficient operation of the } \\
\text { workflow, project and financial management } \\
\text { systems }\end{array}$ \\
\hline $\begin{array}{l}\text { ICT creation of business value (not only } \\
\text { productivity enhancements but also, } \\
\text { competitive advantage, inventory reduction, } \\
\text { new organizational capability among other } \\
\text { factors) }\end{array}$ & $\begin{array}{l}\text { Improve decision-making based/on } \\
\text { visualizations and simulations/improved } \\
\text { information sharing and } \\
\text { transparency/improve efficiently and } \\
\text { effectively }\end{array}$ \\
\hline $\begin{array}{l}\text { Ensures faster delivery of projects and services } \\
\text { to clients }\end{array}$ & $\begin{array}{l}\text { More feedback/mass customized product } \\
\text { creation }\end{array}$ \\
\hline $\begin{array}{l}\text { Improve planning/creation of a } \\
\text { "knowledge/experience" database }\end{array}$ & $\begin{array}{l}\text { Reduces information losses/helping to reduce } \\
\text { waste of time and resources }\end{array}$ \\
\hline
\end{tabular}


Table 1. (continued)

\begin{tabular}{l|l}
\hline Reducing wastes of resources & Drives internal and external innovation \\
\hline $\begin{array}{l}\text { Receive/send data in almost } \\
\text { real-time/Automated Construction/increase } \\
\text { ability to simulate, analyze, and optimize } \\
\text { production }\end{array}$ & $\begin{array}{l}\text { Reduction of construction time and } \\
\text { production costs/development of } \\
\text { sustainable built environment }\end{array}$ \\
\hline Reduce the amount of construction rework & Reduction carbon emissions \\
\hline Rapid data acquisition/progress control & reduction of the direct or indirect costs \\
\hline Improved performance & Increase safety \\
\hline $\begin{array}{l}\text { Track concrete trucks with RFID technologies } \\
\text { and Building information modelling to reduce } \\
\text { quantity of cement and wastes }\end{array}$ & $\begin{array}{l}\text { Support the improvement sustainability of } \\
\text { the construction sector, namely, in } \\
\text { environmental terms }\end{array}$ \\
\hline $\begin{array}{l}\text { Enhance the level of incorporation of 4,0 } \\
\text { concepts to achieve sustainable development }\end{array}$ & $\begin{array}{l}\text { Improvements and automatize design choices } \\
\text { in terms of construction issues }\end{array}$ \\
\hline Increase cooperation & Monitoring the ambient vibration \\
\hline Energy use tracking & Improve training \\
\hline
\end{tabular}

\section{Analysis}

All of the studies selected aimed to highlight the contributions of digital technologies or approaches to the construction sector. They can be grouped and summarized in the following table. The first one, Table 2, presents the main gains noted on at least six occasions during our review and generally credited to the BIM approaches (as we had noticed in a completely different study relative to the BIM Maturity Model [2]).

Table 2. First set of observed gains.

\begin{tabular}{l|l|l|l|l|l}
\hline $\begin{array}{l}\text { Productivity or } \\
\text { efficiency }\end{array}$ & $\begin{array}{l}\text { Sustainability } \\
\text { approach }\end{array}$ & Cost profit & $\begin{array}{l}\text { Cooperation, } \\
\text { collaboration or } \\
\text { interoperability }\end{array}$ & Information & Quality \\
\hline 26 times & $\mathbf{1 3}$ times & 11 times & 8 times & 8 times & 6 times \\
\hline
\end{tabular}

However, the summary in Table 3 reveals six of the most frequently achieved "original" improvements to be credited to technologies such as IoT [3], drones [4], and 3D printing [5], the latter facilitating, for example, prefabrication. Artificial Intelligence and Cloud Computing are presented as solutions of interest in the improvement of feedback or in the automation of choices [6, 7].

This final synthesis makes it possible to highlight new functions to open, in detail, new perspectives for construction companies. Indeed, more and more real-time monitoring is being studied and used. These follow-ups of objects and participants now make real-time simulations and optimization possible (for example, for flows, time or resources) [8, 9]. 
Table 3. New improvements and prospects.

\begin{tabular}{l|l|l|l|l|l}
\hline $\begin{array}{l}\text { Real-time } \\
\text { track } \\
\text { monitoring } \\
\text { data } \\
\text { acquisition }\end{array}$ & $\begin{array}{l}\text { Optimization, } \\
\text { simulation (real } \\
\text { time) }\end{array}$ & $\begin{array}{l}\text { Customisation, } \\
\text { Pre-fabrication }\end{array}$ & $\begin{array}{l}\text { Resource } \\
\text { management } \\
\text { and } \\
\text { optimization }\end{array}$ & Feedback & $\begin{array}{l}\text { Production } \\
\text { control }\end{array}$ \\
\hline 12 times & 7 times & 5 times & 4 times & 4 times & 3 times \\
\hline
\end{tabular}

The monitoring of planning and the creation of a knowledge and experience database are also being tested and could be generalized [10]. These elements are therefore likely to provide new sources of interest or questioning of companies... Whereas BIM is only occasionally used by less than one third of French companies [11].

Finally, this observation opens up new research perspectives, which are described in more detail in the last part of this article.

\section{Conclusions and Perspectives}

This literature review first confirmed that 4.0 technologies, generally associated with the manufacturing sector, are already benefiting from some precursors of the construction industry. Among the hundreds of studies conducted by academics and companies in this sector, the sixty or so analyzed here have confirmed that the reasons for the existence of BIM (i.e., to improve productivity, communication, quality, or to reduce costs) is reinforced by all of these complementary technologies. The latter, which is increasingly robust and accessible due to their massive diffusion, also make it possible to obtain new and promising functionalities or gains, such as real-time data acquisition to increase reactivity or to optimize process and simulations. As we recall, this exceeded the expectations that had initially been set during the deployment of BIM. However, the companies we met and worked with are still hesitant and limited in terms of financial resources. This analysis now needs to be continued, and for us to become even more proactive. This is why, as with ongoing studies concerning the complementarity between LEAN and Ind4.0 [12], we will attempt to answer the following nested research questions in future collaborative work:

i. Do the skills acquired by companies in deploying and operating BIM provide easier access to new "4.0" functionalities and gains summarized in Table 3?

ii. Conversely, will the acquisition and mastery of new "4.0" technologies facilitate BIM implementation?

iii. Will the two approaches soon be inseparable, BIM becoming the equivalent of the digital twin as defined by Grieves et al. for the construction sector (as already suggested by many companies today [13]) [14]?

iv. ...or will they remain without real mutual effects? 
In order to answer these questions, in early 2020, we have begun major studies and support work with one of France's leading construction companies involved in numerous rehabilitation and new construction programs in the area around Paris.

\section{References}

1. Kagermann, H., Lukas, W.-D., Wahlster, W.: Industrie 4.0: Mit dem Internet der Dinge auf dem Weg zur 4. industriellen Revolution, VDI nachrichten, vol. 13, p. 2011 (2011)

2. Joblot, L., Paviot, T., Deneux, D., Lamouri, S.: Building information maturity model specific to the renovation sector. Autom. Constr. 101, 140-159 (2019). https://doi.org/10.1016/j.aut con.2019.01.019

3. Correa, F.R.: Cyber-physical systems for construction industry. In: IEEE Industrial CyberPhysical Systems, ICPS 2018, pp. 392-397 (2018). https://doi.org/10.1109/ICPHYS.2018. 8387690.

4. Tezel, B.A., Aziz, Z.U.H.: From conventional to IT based visual management: a conceptual discussion for lean construction. ITcon 22, 220-246 (2017)

5. Cangelli, E., Conteduca, M.: Architecture on demand. New scenarios for the design project and the construction industry. TECHNE 16, 96-104 (2018). https://doi.org/10.13128/Techne23036.

6. Khan, K.I.A., Flanagan, R., Lu, S.L.: Managing information complexity using system dynamics on construction projects. CME 34(3), 192-204 (2016). https://doi.org/10.1080/01446193. 2016.1190026.

7. Trani, M.L., Cassano, M., Todaro, D.: Standard information for construction equipment in a relational database. In: présenté à ISEC 2017 - 9th International Structural Engineering and Construction Conference: Resilient Structures and Sustainable Construction (2017)

8. Laurini, E., Rotilio, M., Lucarelli, M., De Berardinis, P.: Technology 4.0 for buildings management: from building site to the interactive building book. In: ISPRS Annals of the Photogrammetry, Remote Sensing and Spatial Information Sciences, vol. 42, pp. 707-714 (2019). https://doi.org/10.5194/isprs-Archives-XLII-2-W11-707-2019

9. Favier, A., Scrivener, K., Habert, G.: Decarbonizing the cement and concrete sector: integration of the full value chain to reach net zero emissions in Europe. In: présenté à IOP Conference Series: Earth and Environmental Science, vol. 225 (2019). https://doi.org/10. 1088/1755-1315/225/1/012009

10. Tibaut, A., Zazula, D.: Sustainable management of construction site big visual data. Sustain. Sci. 13(5), 1311-1322 (2018). https://doi.org/10.1007/s11625-018-0595-9

11. AxeoBIM - Plateforme collaborative BIM : Observatoire du BIM 2018 [En ligne]. Disponible sur (2018). https://www.axeobim.fr. [Consulté le: 23-janv-2020]

12. Rosin, F., Forget, P., Lamouri, S., Pellerin, R.: Impacts of Industry 4.0 technologies on Lean principles. IJPR, 1-18 (2019). https://doi.org/10.1080/00207543.2019.1672902

13. Le jumeau numériquelSNCF Réseau (2019). https://www.sncf-reseau.com/fr/entreprise/new sroom/sujet/innovation-jumeau-numerique. [visited le: 1-janv-2020]

14. Grieves, M., Vickers, J.: Digital twin: Mitigating unpredictable, undesirable emergent behavior in complex systems. In: Transdisciplinary Perspectives on Complex Systems, pp. 85-113 (2017). Springer 
Open Access This chapter is licensed under the terms of the Creative Commons Attribution 4.0 International License (http://creativecommons.org/licenses/by/4.0/), which permits use, sharing, adaptation, distribution and reproduction in any medium or format, as long as you give appropriate credit to the original author(s) and the source, provide a link to the Creative Commons license and indicate if changes were made.

The images or other third party material in this chapter are included in the chapter's Creative Commons license, unless indicated otherwise in a credit line to the material. If material is not included in the chapter's Creative Commons license and your intended use is not permitted by statutory regulation or exceeds the permitted use, you will need to obtain permission directly from the copyright holder.

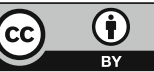

